\title{
Overview of Cretaceous Non-Marine Deposits and Their Palaeoclimatic Characteristics in the North of Vietnam
}

\author{
Nguyen Xuan Khien', Nguyen Thi Minh Ngoc $^{2}$ \\ ${ }^{1}$ Vietnam Union of Geological Sciences (VUGS), Hanoi, Vietnam \\ ${ }^{2}$ Faculty of Technology \& Information Security, PSA, Hanoi, Vietnam \\ Email: khien@vigmr.vn
}

How to cite this paper: Khien, N.X. and Ngoc, N.T.M. (2019) Overview of Cretaceous Non-Marine Deposits and Their Palaeoclimatic Characteristics in the North of Vietnam. Open Journal of Geology, 9, 688-691.

https://doi.org/10.4236/ojg.2019.910076

Received: August 17, 2019

Accepted: September 22, 2019

Published: September 25, 2019

Copyright $\odot 2019$ by author(s) and Scientific Research Publishing Inc. This work is licensed under the Creative Commons Attribution International License (CC BY 4.0).

http://creativecommons.org/licenses/by/4.0/

\begin{abstract}
The Cretaceous non-marine deposits play an important role in the history of formation and evolution of Earth's crust in northern territory of Vietnam. According to analyzing results of material composition and depositional environments, these deposits can be divided into three lithofacies assemblages, such as proluvial-deluvial, fluviatile and lacustrine lithofacies. These Cretaceous non-marine sequences in the North of Vietnam indicate a typically continental hot and dry palaeoclimatic regime.
\end{abstract}

\section{Keywords}

Cretaceous, Non-Marine, Lithofacies, Palaeoclimate, Ripple-Marks, Shrinkage Cracks, North of Vietnam

\section{Introduction}

The Cretaceous non-marine sequences are all located in almost structural zones in northern territory of Vietnam in the various forms, depending on the influence of regional tectonic and erosional regimes. Stratigraphically, in accordance with the differentiation of material composition and the conditions of depositional environments, these sequences can be divided into four stratigraphical units [1]: i.e. the Ban Hang Formation $\left(\mathrm{K}_{1} b h\right)$ in Northeastern area, the Nam Ma Formation $(\mathrm{Knm})$ in Muong Te zone, the Yen Chau Formation $\left(\mathrm{K}_{2} y c\right)$ in Northwestern area and the Phu Co Pi Formation $\left(\mathrm{K}_{1} \mathrm{pc}\right)$ in North Central Vietnam. Three lithofacies assemblages were distinguished and many palaeoclimatic signals can be reflected. 


\section{Geological Setting}

Although with a stratigraphical discontinuity, the Cretaceous non-marine deposits $(350-1400 \mathrm{~m})$ in northern Vietnam are characterized by two types of sections:

1) They unconformably overlie on the Lower and Middle Jurassic. In fact, they occur in every geological structure units (the Ban Hang Formation, the Nam Ma Formation and the Phu Co Pi Formation).

2) They unconformably overlie on other older rocks (the Yen Chau Formation).

\section{Lithofacies and Depositional Environment Characteristics}

Based on material composition and forming conditions, the non-marine Cretaceous of northern Vietnam can be included into the following lithofacies assemblages [2]:

1) Assemblage of proluvial, proluvial-deluvial lithofacies, consisting mainly of breccia-conglomerate, gravel-bearing conglomerate. The rocks of this lithofacies association were formed during the early stage of the sedimentary basin.

2) Assemblage of fluviatile lithofacies, consisting of:

a) Channel facies, composed mainly of poorly to moderately sorted, moderately to poorly rounded polymictic gravelstone, with lenses of gravel-bearing coarse grained sandstone, at some places interbedded with sandstone and sandy siltstone of aluvial lithofacies. The main structure is unclear bedding and monoclinal cross-bedding.

b) Aluvial facies, composed mainly of medium to fine grained sandstone with horizontal ripple-mark bedding structure or monoclinal cross-bedding, directly overlying the rocks of channel lithofacies.

3) Assemblage of lacustrine lithofacies composed of well rounded and well sorted, fine grained sandstone, siltstone, mudstone, gypsum/salt. Their structure is gentle or nearly horizontal, with ripple-marks at some places.

\section{Palaeoclimatic Characteristics}

Generally, typical Cretaceous non-marine sequences in northern Vietnam are all characterized by multi-provenance terrigenous sediments, from coarse-grained to fine-grained, reddish brown, brownish red in colour, uneven bedded structure. The palaeoclimatic analyses show that they contain many signals indicating a typically continental hot and dry palaeoclimatic regime [3] [4]. The evidence is as follows:

1) The primary red, reddish brown, brownish red colors are by the presence of hematite, goethite, limonite and lepidocrocite which are unevenly scattered in the sediments. $\mathrm{Fe}_{2} \mathrm{O}_{3}$ content tends to increase in accordance with the decrease of sediment's grainsize;

2) The presence of gypsium/anhydrite and salty trace, is especially in northwestern areas and Muong Te zone. Gypsium/anhydrite exists in these sedimentary 
rocks in 3 forms:

a) Thin layers (thickness is ranging from 1 to $14 \mathrm{~cm}$ ), synsedimentation.

b) Unevenly disseminated, authigenical existence in component of different rocks, such as claystones, silstones, sandstones with content ranging from 3\% $5 \%$ to $10 \%-15 \%$, significantly to $30 \%-35 \%$.

c) Secondary vein/nest type filled in rock fissure systems.

3) Polygonal sand-filled shrinkage cracks on the surface of claystone layers.

4) The Cretaceous non-marine sediments are always very poor in organic material caused by dry and hot continental paleoclimate. The pelecypod fauna consists of species living in fresh and brackish water environment, such as Hoffetrigonia kobayashi, Unio sp., Trigonioides sp., Cardinioides sp. [5]. Plant fossils have leaf-shape with entire margins which are as a reflection of droughty palaeoclimate [2].

5) Trace element analysis of 26 samples gives the following values (\%): $\mathrm{Fe}$ (1.26 - 9.21), $\mathrm{Al}(1.02$ - 11.13), Ti (0.32 - 0.47), $\mathrm{Ca}(0.42$ - 7.43), P (0.045 - 0.080), Co $(10-21 \mathrm{~g} / \mathrm{t}), \mathrm{Ni}(10-44 \mathrm{~g} / \mathrm{t}), \mathrm{Cr}(40-128 \mathrm{~g} / \mathrm{t}), \mathrm{Ba}(71-869 \mathrm{~g} / \mathrm{t})$ and $\mathrm{Zr}(15-$ $420 \mathrm{~g} / \mathrm{t})[3]$.

The rare earth element (REE) composition in Cretaceous sedimentary rocks of different sedimentary basins of northern Vietnam as shown in chondride-normalized spider diagram does not display any considerable differentiation. Furthermore, ratio between $\mathrm{Ce} / \mathrm{La}$ content is always $<1.5$ (the average ratio based on 43 samples is 1.48) which is characterized for rich of oxygen in continental sedimentation environment.

Clearly, with such signs as mentioned above, the Cretaceous non-marine sedimentary rocks in northern Vietnam are formed under a typical hot and dry palaeoclimatic regime.

\section{Acknowledgements}

The authors wish to thank Prof. Phan Cu Tien (Vietnam Institute of Geosciences and Mineral Resources) and to Prof. Jingeng Sha (Nanjing Institute of Geology and Palaeontology) for their encouragement as well as the constructive suggestions. This is a contribution to UNESCO/IUGS/IGCP 679.

\section{Conflicts of Interest}

The authors declare no conflicts of interest regarding the publication of this paper.

\section{References}

[1] Khien, N.X. (2005) Stratigraphy of Cretaceous Non-Marine Red-Beds in the North Vietnam. Journal of Earth Sciences, 1, 82-88.

[2] Miall, A.D. (2000) Principles of Sedimentary Basin Analysis. Springer, Berlin. https://doi.org/10.1007/978-3-662-03999-1

[3] Huu, L.T., et al. (2004) Some Characteristics of Non-Marine Gypsum-Bearing Se- 
diments in Yen Chau Formation. The Geology and Minerals of Vietnam. The Northern Mapping Department, Gen. Dep. Geol. \& Min. of Vietnam. Hanoi.

[4] Khien, N.X. (ed.) (2003) Sedimentology and Paleogeography of the Cretaceous-Jurassic Red-Beds and Related Mineral Resources in North Vietnam. Dept. of Geology \& Minerals of Vietnam, Hanoi, Vietnam.

[5] Sha, J.-G., Meesook, A. and Khien, N.X. (2012) Non-Marine Cretaceous Bivalve Biostratigraphy of Thailand, Southern Lao PDR and Central Vietnam. Journal of Stratigraphy, 36, 383-400. 